\title{
8
}

\section{Lessons to be learned from the EU policy towards Mercosur}

\section{Introduction}

Russia and China, as well as partners in Latin-America, deserve a clear European strategy. Africa has, unfortunately, been absent from the EU's strategic agenda for years and needs to be reengaged ... The Union can be a global actor considering we possess the objectives, principles and instruments. Unfortunately the political will is often lacking and the question is whether the EU Member States will take action to change this. (Moratinos 2010)

The views of Miguel Angel Moratinos, Spanish minister of foreign affairs and cooperation, in a speech of 20 January 2010, during the Spanish presidency of the EU, recognize a series of gaps in the strategic behaviour, the existence of partiality in the strategic agenda, and a lack of will in EU external relations. This quote suggests that if this was the situation in 2010, then EU policies during the 1980s and 1990s towards a Latin American region such as Mercosur were not the most structured nor were they developed to their full potential. At the same time, the EU's internal institutional and legal frameworks also changed as a result of different treaties and enlargements. These internal changes affected EU relations with Latin America both positively and negatively. On the one hand, the Iberian membership of the EU affected EU policy positively towards Latin America; on the other hand, policy towards Central and Eastern European countries which culminated in the 2004 enlargement negatively affecting EU-Latin America relations.

This monograph has analysed the reasons behind the EU's strategic actions towards Mercosur from 1985. The dependent variable has been the degree of engagement the EU demonstrated in its policy. It has been assessed in relative terms instead of absolute terms with the analyses of two criteria: ambition and commitment.

In relation to ambition, the focus has been on what the actor - the EU - wanted, desired and aspired to do. This book has analysed ambition by looking at how far the EU tried to shift away from its status quo, examining 
EU policy pronouncements and long-term plans in relation to Mercosur. With regard to commitment, the focus is on what the actors promised to do or say - and a review of how much of this was done. It is crucial to reflect how hard the EU tried to achieve its objectives and at what price it did so. The number of meetings and the rank of the actors present at those meetings are a way of assessing this. Another indicator was the funding or aid agreed by the EU for Mercosur.

More specifically, this study has analysed the way that the most important policy-makers from both the Council and the Commission as a whole, and individuals within each institution, have positioned themselves during different stages of the policy-making process. This has brought new insights on two important fronts: first, it has shed light on the different arguments in the existing literature which seek to explain the development of EU foreign policy towards Mercosur; and secondly, the results have been examined in relation to the findings in wider and more general debates on EU foreign policy, particularly in relation to the notion of the EU as a global actor.

To complement this analysis, this book has examined the different arguments in the literature on EU policy towards Mercosur at the different stages in order to examine their real explanatory capacity over time. In doing so, this study contributes to an incomplete debate on the reasons behind EU foreign policy towards Latin America, and Mercosur in particular. These findings are relevant in that they contribute to what is a puzzling debate on EU foreign policy in terms of both theoretical and empirical issues by paying special attention to the important discussion on the EU as a global actor. Such a debate is so crucial that it is mentioned continually in official EU views, such as those expressed above by Miguel Angel Moratinos.

This monograph finds considerable evidence of how the EU has been a responsive actor to Mercosur demands at the different stages of the relations instead of being a strategic actor that has initiated EU-Mercosur relations. This argument also corresponds with the work of Jorg Monar (1997), who suggests that third parties are the actors who have sought to upgrade EU-Mercosur policies. It also shows how the Iberian membership created a crucial juncture in the development of EU relations towards the region. Finally, this analysis also implies that the EU is far from being interested in the region in general and that the development of this policy was only possible due to the influence of both Spain and Portugal and the proactive behaviour of Mercosur. The actions of Spain and Portugal and the EU's reaction to them in relation to Mercosur can be identified as a consequence of the path dependence created with the Iberian membership. This undermines the argument that considers the EU to be a global actor. As Miguel Angel Moratinos claims, the EU has the capacity but not the will to develop relations with certain regions such as Africa which are treated differently 
from others; whilst the EU has not developed a clear and coherent strategy in relation to Latin America.

The remainder of this chapter is divided into three sections. The first section will summarize the most important findings provided by this study. It will then translate these findings into a broader discussion on EU foreign policy towards Mercosur in the second section. Other explanations for the development of EU-Mercosur relations that can be found in the existing literature will be examined in the third section. The chapter will then be concluded by developing an analysis of the role of the EU as a global actor.

\section{Empirical evidence of EU-Mercosur relations}

In order to understand fully the conclusions reached in this monograph, it is important to summarize the findings presented in the previous chapters. This section will begin by discussing the concept of the strategic actor by focusing on the lack of proper EU strategy towards Mercosur. This will then be followed by a discussion of EU internal actors and an examination of which actors have shown the most interest in developing EU strategy towards Mercosur.

\section{Lack of strategy?}

This section discusses the issue of the existence of a strategy to some extent. Without claiming that there is a complete lack of an EU strategy, there are flaws in EU behaviour. In fact, the EU's actions can be seen as being at the lowest degree of 'strategic'. Therefore, it could be said that the EU is strategically weak. We will first focus on the actions of the EU and move on to look at the actions of Mercosur. The actions of the latter will be used to undermine the suggestion that the EU has been a strategic actor.

As this monograph pointed out in the first chapter the conceptual contribution is related to the definition by Smith and Xie (2010) of the concept of strategic actor. As was stated in the introduction, for an actor to hold a strategy, he or she should undertake consistently intentional actions. Therefore, following the definitions of Moore (1959), 'design for action', or Drucker (1974) 'purposeful action', and Mintzberg (1987), who relies on the work of the former, a strategy should have consciously intended actions.

In general terms the EU strategy towards Mercosur should have a plan, an objective(s), the resources to reach that objective, the capacity to become a 'EU' plan in the sense that it involves all the EU actors. It must also have a strategy that is flexible enough to accommodate changes in the international scene. This monograph has shown that the EU fails to do this. However, this definition does not cover all the aspects of 'strategic' actor. This definition should have a part dedicated to the 'intentionality' behind 
the strategy. The actor holding a strategy needs to undertake consistently intentional actions. This study has tried to make a conceptual contribution to Smith and Xie's definition of the importance of 'intentionality'.

Mintzberg himself highlights the part of the definition that Smith and Xie do not develop - 'consciously intended'. As he says, it has to be developed consciously and purposely. The significance of the intentionality behind the action is that otherwise, accidental actions would be considered strategies. This would mean that some actors would seem to be what they are not and would be described as strategic players when it was not the case. It is necessary to explain that the development of patterns of behaviour without previous preconceptions should not be considered strategies, which goes against Mintzberg's argument: 'Thus, the definition of strategy as plan and pattern can be quite independent of each other: plans may go unrealized, while patterns may appear without preconceptions. To paraphrase Hume, strategies may result from human actions but not human designs' (Mintzberg 1987: 13).

Moreover, in the opposite case, inaction should not be considered a strategy either. This monograph argues explicitly that, for example, ignoring Mercosur or not giving Mercosur the attention that would be expected from a global actor such as the EU, should not automatically be considered a strategy, the strategy of 'indifference'. If the EU was doing this on purpose it would have reasons to do so, and a plan that explains that indifference is going to show a pattern due to certain reasons. But, for this to be the case, the EU would have to know Mercosur well and have reasons that support this planned indifference. This point will be developed further in the conclusions.

In terms of 'interest', the actor does not need to have interest in the object affected by its strategy, since it could be part of a bigger plan. In other words, the EU could develop a strategy towards Mercosur as part of a global EU strategy and have no interest whatsoever in Mercosur per se. Mercosur could be the method through which to achieve something and not the end in itself. Therefore, 'interest' is not a necessary part of the definition.

In relation to the EU and Mercosur it is clear that for the period covered in this monograph, there was not a strategy. Drawing on the work of Smith and Xie (2010), the analysis offered here has been contextualized within the framework of what it takes for the EU to be a strategic actor. Smith and Xie argued that the EU 'must demonstrate the capacity to extract and mobilise resources from its Member States and other relevant sources, and to do so consistently over a period of time' (Smith and Xie 2010: 5). The findings in this monograph suggest that there is a consistent extraction/ selection of resources towards Mercosur especially in relation to the transfer of know-how, which can be seen in the multi-annual strategic papers delivered by the Commission. However, caution is needed in the analysis 
of the importance of that fact since this monograph has proved how the actual amount of resources is significantly smaller than those provided to other regions, especially for Central and Eastern European countries since 1989. The pyramid of preferences also proves how Mercosur has been continually placed at the bottom of the pyramid. Smith and Xie also contend that the EU 'must show that it is possible to relate these resources to agreed medium and long term objectives, and to act positively in line with those objectives' (Smith and Xie 2010: 5). The four empirical chapters demonstrated that the objectives of the EU were never part of a clear long-term plan and, in fact, these objectives repeatedly changed over time. Chapter 4 showed how the EU had barely started to consider a policy towards Latin America in general, let alone have specific objectives towards the region. In Chapter 5, the discussion of EMIFCA proved just how unclear the EU's objectives towards Mercosur actually were because the Commission suggested three different policy options. In addition to this, Chapter 6 recounted how it was only at the last minute that the EU reached the decision to start negotiations with Mercosur, which suggests the decision was not well planned and strategically organized. Chapter 7 also demonstrated how it was necessary again to have a Spanish presidency and the interest in Latin America to relaunch the negotiations. Even the Venezuela of Chavez encouraged Mercosur to negotiate with the EU despite this new member of Mercosur being unable to participate in the negotiations. Alongside these negotiations with Mercosur, it has been shown that the EU developed a special partnership with one Mercosur country alone - which challenges the notion of the EU having a well-rounded and coherent policy towards Mercosur as a whole.

Smith and Xie also argue that the EU 'must demonstrate that it is capable of generating a strategic narrative that shapes the expectations of both its member States and other EU bodies and also its key international interlocutors' (Smith and Xie 2010: 5). In Chapter 6, it was shown that the EU did not match the expectations and desires of Mercosur. More specifically, it was shown that both parties were unable to reach an agreement. Chapter 7 demonstrated how it is even more difficult to reach agreement this time, considering the international financial crisis, the new EU members and the situation of Argentina, even though the Transatlantic Trade and Investment Partnership negotiations are certainly putting even more pressure on Mercosur. Furthermore, in Chapter 4 it was also demonstrated that the EU failed to match the interests of member states such as Spain and Portugal, who tried to secure a more substantial set of commitments from the EU. In addition to this, it was suggested in Chapter 5 that there was a clear difference in expectations of the Commission and the Council during the setting up of EMIFCA, where it was apparent that there was clear disagreements within the Council. Smith and Xie contend that the EU 'must be able to adapt its aims, its resource allocations and its strategic narrative to 
changes in the global context and to challenges that emerge from its developing international activities' (Smith and Xie 2010: 5). The fact that the negotiations in the third stage (Chapters 6 and 7) were so linked to the state of affairs in the WTO proves how inflexible the EU was being in its relations with Mercosur. Interestingly, Smith and Xie recognize that the EU has developed strategies and in fact many of these strategies were developed through the Commission. Nevertheless, this does not mean that the Commission can be referred to as a strategic actor.

The EU did not have a design for action nor a purposeful plan of action because, apart from other reasons, it did not know what to do with Mercosur, as is demonstrated in the different stages. In fact, it was Mercosur that was offering the possible upgrades of policy. The EU did not have any sort of consciously intended actions at all, since it did not know the region; it was brand new to this area of external relations until the Iberian membership. The EU did not have a long-term plan.

This monograph denies the consideration of accidental actions as strategies to avoid the characterization of 'strategic actor' being mistakenly attached to a player when it is not appropriate. The EU's actions are closer to accidental than to anything else due to the lack of strategy over time and the fact that the steps taken were promoted by Mercosur. In a way, the 'brain/thinker' of the strategy/plan was not the EU but Mercosur.

When a strategy remains unnoticed even for the player exercising the strategy, it does not mean that there is not a strategy in itself, but that the player is not conscious of the strategy, which is different from an accidental action. In this case, the EU did not have a strategy; it is not that it was not aware of what was going on because only the Commission knew the plan, or just a few EU states were aware of what was going on. Simply put, there was not a strategy. In fact, with the lack of knowledge of the region, it was impossible that there could have been an unconscious strategy. This lack of knowledge is what makes it easy to prove that the EU did not have a strategy of 'indifference'. In order to have had such a strategy, the EU would have had to know what it was ignoring and why, which was not the case. The EU was ignoring Mercosur countries until the Iberian membership, but this was due to ignorance, not as a consequence of a deliberate plan.

\section{Mercosur's initiatives}

This book has also established that there is enough evidence to suggest that Mercosur's demands on the EU were a direct cause of the developments in the relations between the two regions. This supports the argument put forward by Jorg Monar (1997), who suggests that third-party groups take the initiative and ask for upgrades in relations and/or policies with the EU. In the case of Mercosur, it was shown in Chapter 5 that this happened from 
the very first moment that EU-Mercosur relations started to develop. In fact, before Mercosur became a regional group ratified by its member states, there was a meeting between the EU and the South American group. This sequence of events explains the speed at which things occurred. In March 1991 Mercosur signed the Treaty of Asunción which created Mercosur, although ratification of this treaty did not take place until the end of the year. In April 1991 Mercosur countries met with the EU in Brussels as part of the annual meeting with the Rio Group. This gathering was the first formal institutionalized meeting of the Rio Group. Two days after this meeting, Mercosur met with the European Commission in order for the two groups to develop inter-regional relations. As a result of this meeting, the first agreement on the transfer of knowledge was signed on 2 May 1992. At the EU-Rio Group annual meeting that took place at the end of May, the two groups reached an inter-institutional agreement. However, this agreement was not enough for Mercosur, and after these events, the ministers of Mercosur countries asked the Commission to work on possible ways of improving relations. Mercosur had already criticized the EU's agricultural protectionism. During the annual EU-Rio Group meeting in 1993 there were discussions about improving relations. Once again it was Mercosur who asked the EU for an upgrade of relations/policies, and this upgrade was developed the next year following the next EU-Rio Group meeting.

The upgrade that the EU offered and signed in 1995 required unanimous agreement of the member states of the $\mathrm{EU}$ in order to start negotiations. Again the pressure applied by Mercosur countries was crucial over the years and especially in the run-up to the first meeting of the heads of states of Latin America and the EU in 1999, as discussed in Chapter 6. The dynamic of third parties demanding commitments from the EU at the start of relations and their upgrading of these commitments was not only characteristic of EU-Mercosur relations. It was demonstrated in Chapters 4, 5, 6 and 7 that this was in fact characteristic of EU-Rio Group relations as well. This set of findings suggests that there was a lack of proactive behaviour by the $\mathrm{EU}$ in terms of developing policies towards Mercosur. It also suggests that the EU was more responsive in its approach to external suggestions. This dynamic could be seen as a consequence of the asymmetries in both groups in terms of economic power, with Mercosur countries being in a weaker economic and political position, as well as the difficulty Mercosur faced when trying to gain access to the EU market.

The discussion so far has explained one half of the argument which suggests that it was Mercosur that showed proactive strategic behaviour towards EU-Mercosur relations, whilst the EU displayed a more responsive approach in reacting to Mercosur's demands. However, the reasons have not yet been discussed. The following section will explore these issues in relation to both the support and opposition for a policy towards Mercosur within the EU. 


\section{Iberian interest versus EU lack of interest}

Once Spain and Portugal joined the EU on 1 January 1986, EU relations with Latin America changed to the point where a 'before and after' line can be drawn. This monograph has presented enough evidence to suggest that the extraordinary interests of Spain and Portugal in their former colonies in Latin America were crucial in the responsive attitude of the EU to Mercosur's demands. Moreover, given the fact that Spain and Portugal are not the most powerful countries within the $\mathrm{EU}$ and that many other EU countries have their own special relationships with their former colonies in Africa, the Pacific and Asia, this policy is almost unexpected. In other words, the Iberian support for Mercosur demands and a very persistent Spanish commissioner in charge of relations with this region made the development of a policy possible against the backdrop of the lack of support and interest in the region shown by the majority of EU member states.

Chapter 4 explained the impact of Iberian membership in terms of official declarations by both the EU and Iberian countries at the time of the signature of the Act of Accession in June 1985. However, the impact that Spain and Portugal could have was lower than expected because of the lack of interest in that region and consequently little more than declarations were achieved instead of real commitments. Iberian support did not only occur at the time of the Iberian membership; it has been a clear feature of the Spanish and Portuguese actions in the different EU institutions over the years. Chapters 5 and 6 have shown how Manuel Marin had to fight within the Commission against the French commissioners and the agriculture commissioner during the launch of the 1995 agreement with Mercosur discussions which were only resolved by an internal voting issue.

In the Council, Spain and Portugal promised support in areas of interest for the other member states in exchange for other members' support on anything related to Latin America (Interview 6). Chapter 5 demonstrated Spanish and Portuguese support for the creation of the 1995 agreement. The continued Spanish and Portuguese calls for supportive action were persistent, especially during the presidencies of Spain and Portugal. It is not a surprise that many of the negotiators on the EU side were Spanish, and this issue helped to smooth the negotiation, according to a negotiator from the Argentinean team.

However, all the support and attention given by Spain and Portugal was not automatically replicated by the other member states and commissioners for different reasons. Firstly, in relative terms there was not a significant trade interest on the EU side towards Latin America. Secondly, there are other former colonies of other member states such as the UK and France that continue to be prioritized over Latin America in the EU because Spain and Portugal are not as powerful as the UK and France (see Chapters 5 and 6). Thirdly, from the moment that Eastern European countries became 
independent from the former Soviet Union, the EU focused politically and economically on them until most of them became member states in 2004 (see Chapters 4, 5 and 6). During the second attempt to negotiate the agreement (Chapter 7) these Eastern European countries became part of the negotiating team since they are part of the EU and some of them have a special interest in the agricultural sector (e.g. Poland). What was once EU foreign policy is now part of what the EU actually is, and therefore part of what it wants. In relation to the last two points, the discussion of the substance of the agreements in Chapter 4 highlighted the intentions of the $\mathrm{EU}$ in relation to different groups of countries. The legal material in agreements with ACP or Eastern European countries, and the absence of it in relation to Mercosur, shows the lack of interest in that group by the majority of EU member states. Moreover, even in the official documents in which Mercosur is mentioned, it is not clear which kind of interest - if there was any interest at all - the EU showed towards Mercosur (see Chapters 5, 6 and 7). Therefore, the EU had a lack of interest towards Mercosur compared with other external relations, but that should not undermine the importance of Mercosur within the EU-Latin America relationship. Mercosur was such a priority within EU relations towards Latin America that to some extent, as explained in Chapter 3, EU policy towards Latin America was synonymous with EU policy towards Mercosur. And, as has been explained in Chapters 5 and 6, the EU had a clear interest towards Mercosur as a region, an interest slightly superior to its interest in Mercosur countries individually. In fact, the EU prioritized agreements with the region over individual agreements.

Finally, as mentioned earlier, the possibility of the EU having a consistent policy of neglect towards Mercosur could be sustained only if the EU knew Mercosur countries and institutions well, and if the EU disliked the region/ countries, and had an argument against the country/region. Central to the argument developed in this monograph is the fact that the EU did not care enough about Mercosur since it had a very reactive attitude and Mercosur had to be the proactive player, together with Spain and Portugal. This monograph it is not claiming that the EU did not care at all about Mercosur because in that case there would not have been a policy at all.

\section{What does the evidence tell us about EU policy towards Mercosur?}

The study of the degree of EU engagement towards Mercosur has been developed through the whole of this monograph. At the different stages, there have been different outcomes but, as has been shown, the tendency was to increase both ambition and commitment at each stage, which is paradoxical since the path dependence was created in the first stage. It might have been expected that the EU would have great ambition and commitment at that stage which might or might not have continued. 


\section{Ambition}

At the first stage, the level of ambition was low. There were some moves towards the development of new guidelines; the declaration of the EU and the Iberian countries independently from the Treaty of Accession - as Spain and Portugal wanted - from a legal point of view, showed a low level of ambition as well. In the second stage ambition was medium, due to several pieces of evidence showing growing ambition on the EU side. The guidelines established new goals towards Latin America and the first proper guidelines towards Mercosur showed a positive ambition. Also the agreement on the association agreement was important for the level of ambition. However, the requests from the Latin American side in relation to loans from the EIB, the institutionalization of the Rio Group and the development of agreements between Mercosur and the EU undermined the EU ambition shown at this stage. The lack of legal content of the EU-Mercosur agreements did not help increase the level of ambition either.

At the third stage the ambition was high, from the plans to achieve association agreement, as the establishment of the Joint Committee showed. However, the pressure to upgrade the existing EU-Mercosur relations again came from the Mercosur side, which reduces the level of EU ambition. Moreover, the linking of the EU-Mercosur negotiations to the WTO negotiations was evidence against a high level of ambition as well as the attitude of the new commissioners in charge of the agreement, Lamy and Patten.

\section{Commitment}

The meetings with the EU-Rio Group after the San José process are evidence of low but existent commitment at the first stage which should not be confused with none. The level of aid attributed is another example of the level of commitment. At the second stage, the level of commitment is high since these are the most productive years of EU-Mercosur relations. The amount of aid assigned in the guidelines, the upgrading of the investment facilities and the visits of Delors to the region prove that level. But more importantly the signature of two EU-Mercosur agreements in such a short period of time helps the assessment. On the negative side the reorganization of the GSP and the legal emptiness of the EU agreements with Mercosur let down the EU level of commitment.

At the last stage of the policy the assessment of commitment was high. The Joint Committee did not achieve much due to resistance in the EU towards any progress in the development of the association agreement, and the lack of a final agreement in October 2004 evidences a vague EU commitment since the European side was the one linking the EU-Mercosur negotiations with the WTO negotiations. The relaunch of the negotiations also demonstrates a high level of commitment. 
Throughout this monograph there has been a discussion of the arguments that are put forward in the existing literature to explain the reasons behind EU policy towards Mercosur. The different arguments are not completely incompatible with each other, but one thing that they do have in common is that they do not explain the reason behind the development of EU attitudes across all stages of policy development. In some cases they do not really explain the policy at any stage. The last part of this section will discuss these different explanations and why they fail at some stage to explain EU policy towards Mercosur. Table 8.1 shows the final outcomes of the six different arguments in the different stages of the policy.

\section{Counterbalancing the US}

Within the existing literature there is an argument that focuses on the influence that the US already had in Latin America and how the EU was trying to minimize this influence by developing agreements within the sub-regions of Latin America. Since Mercosur covered a vast segment of Latin America, involving the most developed countries in the region apart from Mexico and Chile, and because it can be dealt with as a region it is not a surprise that the EU wanted to achieve relations with Mercosur. Unfortunately, this argument fails in the first and third stages of policy development. In the first stage (Chapter 4), the EU had anything but a plan towards Latin America and it was at this stage that the EU was elaborating ideas and plans. In the third stage (Chapters 6 and 7), again this argument cannot be accepted because the EU was not willing to compromise on economic issues during the negotiations in order to achieve an agreement with the region. In the second stage (Chapter 5), there was some interest and consideration of the US and the creation of NAFTA as a force to develop relations. However, this point should be considered with caution. Not all of the members of the Commission or the Council were thinking in those terms, and definitely not the 'father' of the agreement, Manuel Marin. There was a semblance of consideration of this situation within the directorate general of trade. Some member states, though, admitted that not only was the EU not competing against the US, but the EU could not compete with the US since it was in a weaker position.

\section{Global aspirations}

In the literature, there are also some thoughts about the EU's global aspirations which imply an increase in its involvement in world politics as a whole. As a consequence, the focus of the EU's actions should be an arithmetic progression in EU relations/agreements/partnerships with all the regions in the world. This was not the case during the first and third stages. During the first stage, the EU did not yet have any clear policy objectives 
Table 8.1 Competing arguments at the different stages

\begin{tabular}{|c|c|c|c|c|c|}
\hline $\begin{array}{l}\text { Independent } \\
\text { variable }\end{array}$ & Expectations & $\begin{array}{l}\text { Met at } \\
\text { first stage? }\end{array}$ & $\begin{array}{l}\text { Met at } \\
\text { second stage? }\end{array}$ & $\begin{array}{l}\text { Met at } \\
\text { third stage? }\end{array}$ & $\begin{array}{l}\text { Met at } \\
\text { fourth } \\
\text { stage? }\end{array}$ \\
\hline $\begin{array}{l}\text { Counterbalancing } \\
\text { the US }\end{array}$ & $\begin{array}{l}\text { If the US increases its involvement in LA, the EU should } \\
\text { increase its involvement. } \\
\uparrow U S=\uparrow E U \text { in LA }\end{array}$ & No & Yes & No & No \\
\hline $\begin{array}{l}\text { Global } \\
\text { aspirations }\end{array}$ & $\begin{array}{l}\text { If the EU increases its presence in international affairs, } \\
\text { the EU's involvement in LA should also increase. } \\
\uparrow E U \text { in the world = } \uparrow E U \text { in LA }\end{array}$ & No & Yes & No & No \\
\hline $\begin{array}{l}\text { External } \\
\text { federator }\end{array}$ & $\begin{array}{l}\text { If LA becomes more integrated, the EU will increase its } \\
\text { relations with LA. } \\
\uparrow L A \text { integration }=\uparrow E U \text { in LA }\end{array}$ & Yes & Yes & No & Yes \\
\hline Affinity & $\begin{array}{l}\text { An increase of shared values between the regions should } \\
\text { develop EU policy. } \\
\uparrow \text { LA shared values }=\uparrow E U \text { in LA }\end{array}$ & No & No & No & No \\
\hline Interdependence & $\begin{array}{l}\text { If trade and investment between the EU and LA } \\
\text { increase, EU policy should also increase. } \\
\text { 个LA trade = } \uparrow \text { EU in LA }\end{array}$ & No & No & No & No \\
\hline Iberia & $\begin{array}{l}\text { If the influence of Spain and Portugal increase within the } \\
\text { EU, then the EU's involvement in LA should increase. } \\
\uparrow S P+\text { PT influence }=\uparrow E U \text { in LA }\end{array}$ & Yes & No & No & No \\
\hline
\end{tabular}


towards Latin America as a region or towards individual countries in the region. In fact, EU external relations were not that developed in general. The notion that the EU held global aspirations during the 1980s would certainly be an exaggeration. During the third stage (Chapter 6), the EU proved again not to have much interest in the ratification of EMIFCA, which was done more 'in extremis' as a last-minute decision before a meeting with the heads of state of Latin America. At the time of making an economic commitment to Mercosur, the EU was again not ready to do so and the negotiations stopped in 2004. The pyramid of preference also clearly shows the unequal treatment of regions and countries by the EU, not due to the countries' needs but a result of the EU's interests. The Central and Eastern European countries became the highest priority for EU external relations after 1989, until they became members of the EU in 2004. There was a prioritization of regions due to the economic, security or political interests that the EU might have towards them.

\section{External federator}

The argument which suggests the EU's role was that of an external federator can be accepted in the first (Chapter 4) and second stages (Chapter 5) but not in the third stage (Chapters 6 and 7). Alongside the argument of counterbalancing the US, this is the most common argument in the existing literature. It is clear that the EU had allocated resources to Mercosur institutions and other Latin American regional groups in order to promote regional integration. The EU had even created the Centre for Economic and Financial Research to support regional integration in Montevideo, Uruguay. However, in the second stage of the policy, the EU started to offer agreements to both the Mercosur group and individual Mercosur member states. It is somewhat confusing that the EU was trying to promote different policies with different approaches. By 2007, there was no room for misunderstandings because the EU offered a very ambitious partnership to the biggest country of Mercosur. The EU singled out Brazil, prioritizing it over other countries and placing it at the level of other global players such as China, India and Russia - the BRIC countries. Chapter 7 demonstrates that the EU is not completely against the idea of launching individual agreements with Mercosur countries, rejecting the idea of prioritizing regional integration over trade agreements.

\section{Long-standing political and economic cultural ties}

The EU and Mercosur shared cultural ties as a result of the Mercosur countries being former colonies of some EU states. These cultural ties include languages (i.e. Spanish and Portuguese) and political systems. In the area of political ties, again the fact that some countries were former colonies 
also shaped their political organization. Economically, since the mid-1980s, Mercosur countries embraced open trade policies after the failure of import substitution policies. This argument is not very common in the existing literature and it could be that those political, economic and cultural ties have existed since the creation of the EU (and before) but were not appealing enough for the EU in terms of developing relations with Mercosur. Fundamentally, Latin America did not become any sort of priority for the EU until the Iberian membership.

\section{Interdependence}

The argument in the current literature relating to interdependence is similar to the previous argument but is focused on the trade tendencies at the international level. This is related to increased global interdependence and how this influenced EU-Mercosur relations. It appears that this argument is not applicable at any of the three stages because trade numbers show how the importance of trade with Mercosur is, in relative terms, of minimal importance to the EU.

\section{Spanish and Portuguese influence in the EU}

The Iberian membership of the EU in 1986 seems to have an effect on EU relations with Latin America since there was a distinct 'before' and 'after' phase. A new set of policies were considered towards Latin America and Mercosur which were developed further after 1986. But Spain and Portugal were not amongst the most powerful countries in the EU because they were the new member states and were only just leaving the 'developing country' tag behind them. The further enlargements of the EU in 1995 and then again in 2004 meant that the EU now had twenty-five member states, which diluted the power of Spain and Portugal inside the EU. Therefore, in the last stage of policy development (Chapter 5), it was not possible for these countries to successfully direct significant policy development towards Mercosur. In fact, it was shown in Chapter 4 that the Iberian countries were crucial but not the only force contributing to the development of EMIFCA.

\section{What does this say about EU foreign policy?}

This final section of this chapter will bring together the argument made in the previous two sections in order to develop a wider discussion about the nature of EU foreign policy. Two main arguments will be discussed: firstly, institutionalization/Europeanization as a way of explaining the development of EU foreign policy; secondly, the development of the EU as a global actor. 


\section{Institutionalization/Europeanization}

The crucial importance of the Iberian membership in 1986 for the development of an EU policy towards Mercosur has been discussed in Chapter 3 and in the first section of this chapter. The bottom-up system/procedure can be used to explain to some extent the influence of Spain and Portugal when they became members of the EU, and even before, in terms of developing the EU's interests in Latin America. As a consequence, since 1986 it seems, to a certain extent, that EU relations with Latin America and Mercosur have become increasingly institutionalized. This monograph has proven that the continued efforts of Spanish officials at the national and European level in terms of developing relations with Mercosur were crucial. The bottom-up explanation not only explains relations when the Iberian countries became members of the EU, it also explains Spain's continued desire to influence the EU in its international relations with Latin America.

Following Wong's (2008) work on Europeanization of the five perspectives of national projection - which include the processes of policy projection, policy learning and policy transfer - this monograph explains the Europeanization of Spanish and Portuguese national foreign policies using the uploading model. According to this school of thought, Spain and Portugal would have tried to bring their national foreign policies to the $\mathrm{EU}$ supranational level by influencing the Commission and other EU states about this new policy area. However, the bottom-up approach is limited and there was the indifference and opposition of almost all other EU member states to contend with. It could be said that there has been a partial institutionalization/Europeanization of this policy.

This is not the only time that, as soon as they joined the EU, new members tried to bring their own national foreign policies to the supranational level. When the EU was created the EDF was also created in order to deal with the special relationship between EU member states and some of their former colonies such as France's relation with former colonies in Africa. This approach was further developed once the UK, which had its own relationship with former colonies, also became a member of the EU. It cannot be argued that this is why the bottom-up process never completely materialized. It did not help that there was nothing in Latin America and Mercosur that was of particular interest to the EU. There were no economic incentives because these countries were still developing their economies and political systems. Furthermore, there was not any immediate humanitarian incentive because these countries were the wealthiest countries in Latin America, and Latin America was not, for example, as poor as Africa. Neither were there any security incentives because the problems in Latin America were mainly restricted to local issues which did not threaten EU security as international terrorism would do, for example. Therefore, Latin America is very much a remote region and still very much 
under the influence of the US. This brings us to the question of whether the EU really is a global actor or a partially global actor in international relations.

\section{Is the EU a global actor? Not really}

According to Bretherton and Vogler (2006) the EU's global 'actorness' can be explained in terms of presence, opportunity and capability. Each of these different aspects was outlined in the introductory chapter. In relation to these characteristics, if the EU was to be referred to as a global actor then it needed to behave like a global actor in its dealings with third parties seeking to develop relations with the EU. Secondly, the EU had to want to behave like a global actor. And thirdly, the EU needed to have the capability to behave like a global actor. In its dealings with Mercosur, the EU only behaved like a global actor in terms of developing relations. The EU may have looked like a global actor in terms of its relationship with Mercosur, but did not behave as such despite having the opportunity and capability of doing so. In relation to 'presence', it can be said that in relation to Mercosur the EU did manage to create expectations since Mercosur was the one demanding a relationship and the subsequent upgrading of the relationship. Mercosur's demands could easily be due to the EU presence.

It is in relation to opportunity that the EU failed miserably to achieve its role as a global actor. The EU had nothing to lose with Mercosur. It was not a sensitive issue such as relations with Russia or China, the Cold War no longer constrained international relations and Mercosur was very keen on the development of relations. Therefore, there is no justification for the lack of EU efforts towards Mercosur, other than it was not interested. If that was the case, then the EU cannot use the discourse of global actor. If you are a global actor, that includes the whole world - not everything bar almost a whole continent such as Latin America. It is not that the EU does not want to get involved with a country like Cuba, which for obvious reasons is a very complex and sensitive issue that nobody wants to deal with. But to ignore the whole of Latin America is not justifiable for a global actor; it is justifiable for a regional actor, but that is a different debate.

In relation to capability the EU was not constrained but rather showed a lack of capability since its relations with Mercosur were based on cooperation, political dialogue and trade negotiations at the lowest level possible. The EU cannot justify the lack of agreement with a lack of capabilities.

\section{Conclusion}

This chapter started with a quotation from the Spanish minister of foreign affairs in which he admitted that the EU could be a global actor, but there was no political motivation for it to do so. It could be argued that the EU 
could behave as a global actor but chose not to because it did not have the necessary political will.

This monograph has proved that the reasons behind the EU's actions towards Mercosur were, for a certain period of time, different for the main actors, different EU member states and the Commission. This book has examined the various other explanations of EU foreign policy towards Mercosur provided in the existing literature. For the first time, these explanations have been tested across three distinct stages in the policy development process and as a result this study has contributed to the ongoing debate on EU foreign policy in both general terms and in relation to two specific issues: the institutionalization/Europeanization of foreign policies and the EU's behaviour as a global strategic actor. In conclusion, this monograph has argued that the EU was a responsive rather than proactive actor towards Mercosur over the course of the three distinct phases of EU-Mercosur policy development. 